\title{
What is the clinical applicability of regenerative therapies in dentistry?
}

\author{
Qual a aplicabilidade clínica das terapias regenerativas na odontologia?
}

Giulia Tarquinio DEMARCO'

Laura Borges KIRSCHNICK ${ }^{1}$

Luis Bayardo WATSON' ${ }^{1}$

Marcus Cristian MUNIZ CONDE

Flávio Fernando DEMARCO'

Luiz Alexandre CHISINI ${ }^{1}$

\begin{abstract}
Regenerative therapies have been widely developed in dentistry and it is important to incorporate dentists' knowledge of these new therapies into the dental clinic routine. This study reviewed the literature on regenerative therapies and clinical applications. Tissue engineering has contributed to changes in the paradigm of restorative health sciences. Its pillars underpin the techniques of tissue and organ regeneration. Despite the majority of studies in this field being in vitro, a range of preclinical studies and methodologies has been formed using these principles and they are already being used on humans. The use of platelet-rich plasma and platelet-rich fibrin in surgery as natural scaffolds for the reestablishment of bone and periodontal tissue are often reported in the literature and clinical trials using this approach have shown promising results. Stem cells from autologous dental pulp have been successfully applied in bone tissue regeneration using natural collagen scaffold in humans. In addition, revascularization of the root canal already appears in the literature as a promising alternative to apexification. The principle behind this therapy is the use of the blood clot as a scaffold and the migration of stem cells of the apical papilla to regenerate the dental pulp organ. Final considerations: Although still in the early stages, regenerative therapies can now be used in dental practice. Knowledge of the principles governing these therapies should be understood by the dentist for use in clinical practice.
\end{abstract}

Indexing terms: Fibrin. Platelet-rich plasma. Stem cells. Tissue engineering.

\section{RESUMO}

Terapias regenerativas vem sendo amplamente desenvolvidas na odontologia e o conhecimento destas novas terapias por parte dos dentistas é importante para que elas sejam incorporadas na rotina clínica odontológica. Assim, este estudo revisou a literatura acerca das terapias regenerativas e suas aplicações clínicas. A engenharia tecidual tem contribuído na mudança do paradigma restaurador das ciências da saúde. Seus pilares embasam as técnicas de regeneração de tecidos e órgãos. Apesar da grande maioria dos estudos neste campo ser in vitro, uma gama de metodologias pré-clínicas foi consolidada e estudos utilizando estes princípios já estão sendo empregados em humanos. Á utilização de plasma rico em plaquetas e plasma rico em fibrina como scaffolds naturais em cirurgias para reestabelecimento de tecido ósseo e periodontal são frequentemente relatadas na literatura e ensaios clínicos utilizando esta abordagem demonstram resultados promissores. Células-tronco da polpa dental autólogas já foram aplicadas com sucesso na regeneração de tecido ósseo utilizando scaffold naturais de colágeno em humanos. Além disto, a revascularização do canal radicular já aparece na literatura como uma alternativa promissora frente a opção de apecificação do canal radicular. Esta terapia utiliza como princípio o coágulo sanguíneo como scaffold e a migração das células-tronco da papila apical para regenerar o órgão pulpar. Considerações finais: Apesar de incipientes, as terapias regenerativas já podem ser utilizadas na prática clínica odontológica. O conhecimento dos princípios que regem estas terapias deve ser compreendido pelo dentista para que sejam utilizadas na prática clínica.

Termos de indexação: Fibrina. Plasma rico em plaquetas. Células-tronco. Engenharia tecidual.

\section{INTRODUCTION}

Tissue engineering is a multidisciplinary field that combines principles of physics and chemistry with biological sciences, aiming towards the regeneration of tissues and organs ${ }^{1}$. It is based on a triad composed of stem cells, which are undifferentiated cells with the capacity to originate several cell lines, the scaffolds, which simulate the extracellular matrix and act as a skeleton providing the support for these cells, and growth factors, which are bioactive molecules, mediators of cellular activity, thus regulating their behavior ${ }^{1}$.

Stem cells may present different degrees of potentiality and plasticity, but they always have the capacity for self-renewal ${ }^{2}$. Embryonic stem cells were $t$ he first to be studied presenting pluripotency, i.e. they have the ability to differentiate into all cell types of the adult organism? However, the use of these cells still arouses heated ethical discussion around the world, which has caused researchers to look for alternative sources of adult stem cells, also

\footnotetext{
${ }^{1}$ Universidade Federal de Pelotas, Faculdade de Odontologia. Rua Gonçalves Chaves 457, sala 501, Pelotas, 96015-560, Pelotas, RS, Brasil. Correspondência para / Correspondence to: LA CHISINI. E-mail: <alexandrechisini@gmail.com>.

${ }^{2}$ Universidade do Vale do Taquari - Univates. Lajeado, RS, Brasil.
} 
called somatic stem cells. These, in turn, can be isolated from bone marrow (BMSC), adipose tissue (ASC) and from various regions of the oral cavity. Somatic stem cells are a more favorable source for application in tissue engineering because they do not present ethical impediments ${ }^{1}$.

Gronthos et al. ${ }^{3}$ performed the first isolation of stem cells from dental pulp (DPSCs) and demonstrated, for the first time, that they were able to form a tissue similar to dentin. Because they are somatic cells of mesenchymal origin, they have the capacity to differentiate in all other populations from the embryonic mesenchyme. In this way, it is possible to use them, for example, to produce bone, cartilaginous, muscular and neural tissue ${ }^{1}$.

Subsequent studies have shown that other oral tissues could be a source of stem cells. Cells from the dental pulp of primary teeth (SHEDs), periodontal ligament (hPDLSCs), apical papilla (APSCs), oral mucosa (OMSCs), gingival tissue (GTSCs) and dental follicles (DFSCs) were isolated and defined (Figure 1). These new sources are more readily available and accessible than somatic cells from the bone marrow or embryos. Thus, it is now possible to isolate stem cells from pulp and periodontal tissue from third molars or premolars extracted for orthodontic reasons. In addition, exfoliated deciduous pulp cells also present an excellent option which has contributed to the development of tooth banks that store such organs for future clinical applications ${ }^{1,4}$.

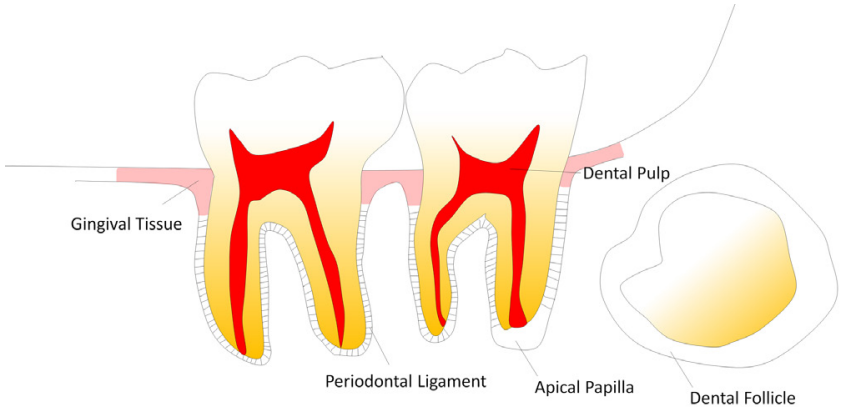

Figure 1. Schematic representation of sites with presence of stem cells in the oral cavity.

With the expansion of these cellular sources, Stem Cell-Based Therapies (SC-BT) have also become a possibility in dentistry2. SC-BT possess bold and innovative strategies to perform the regeneration of pulp tissue using synthetic and autologous scaffolds ${ }^{5-7}$ as well as with bone ${ }^{8}$ and periodontal regeneration ${ }^{9}$. In addition, gene therapy has recently been used to reprogram stem cells genetically by inserting specific genes of interest into the cellular genome. Thus, molecules of interest could be produced by the cellular machinery itself and released according to the needs of the tissue, favoring the reconstruction and/or repair of tissue and organs ${ }^{10}$.

Tissue engineering has led to a change in the reparative paradigm and proposes regenerative dentistry, allowing the reestablishment of the biological functions that synthetic materials cannot perform. Despite being an extremely new field, many studies have been conducted in recent years aimed at the clinical transition of SC-BT ${ }^{2}$. However, such techniques remain remote for the clinical dentist who is often unaware of the possibilities of these therapies. Therefore, the objective of this study was to review the scientific literature in respect of the principles, possibilities and perspectives of clinical transition of regenerative therapies in the field of dentistry, thereby bringing these techniques within the reach of clinical dentists.

Currently, materials used in dentistry, despite demonstrating good clinical performance, are mostly synthetic compounds without biological activity. These materials are able to repair the function of the stomatognathic system, but do not reestablish the biological activity and consequently interactions with the other oral structures ${ }^{1}$. Calcium hydroxide $\left(\mathrm{Ca}(\mathrm{OH})_{2}\right)$ and Mineral Trioxide Aggregate (MTA) are materials widely used by dentists to protect pulp tissue ${ }^{11}$. Although they are synthetic materials, they present bioactive properties through the solubilization of fossilized molecules in the dentin ${ }^{12}$.

This tissue is a large reservoir of biomolecules with biological activity, such as transforming growth factor- $\beta$ (TGF- $\beta$ ) and bone morphogenetic proteins (BMP) ${ }^{12}$. Once these molecules are released, they are able to recruit the stem cells present in the pulp tissue of any dental element. In this way, they migrate to the site of the injury and differentiate into cells similar to odontoblasts, capable of secreting dentin ${ }^{12}$

This common approach in dental practice presents all the principles used in SC-BT. They are based on principles of stem cell differentiation (already present or inserted into the site to be regenerated), initial adhesion to support structures and the use of biochemical mediators (which perform the cell signaling). Despite some regenerative techniques using stem cells already present in the area of the lesion, some techniques require the isolation for later 
application.

\section{Isolation methods for stem cells}

Isolation of stem cells is a very important step and requires extreme caution so that no contamination occurs during the process of tissue transportation and handling. Two methods are used to perform the isolation of mesenchymal stem cells ${ }^{13}$ : 1) Enzymatic digestion; 2) Primary culture or Explant

The collection of the donor tissue (bone marrow, adipose, pulp, periodontal tissue, etc.) is performed similarly in the two techniques. The tissue is extracted from the donor site, conveyed at low temperature in sterile solution and with antibiotics/antifungals to a laboratory where tissue removal is performed with sterile materials. The enzymatic digestion process involves the application of the enzymes collagenase I and dispase in direct contact with the tissue, in order to disaggregate the tissue and obtain cell suspension. In this way, the released stem cells can adhere quickly to the bottom of the culture dish with greater ease ${ }^{14}$. With the explant technique, the tissue does not undergo any method of cell dissociation, however, the tissue is fragmented into several pieces and deposited on culture dishes (Figure 2).

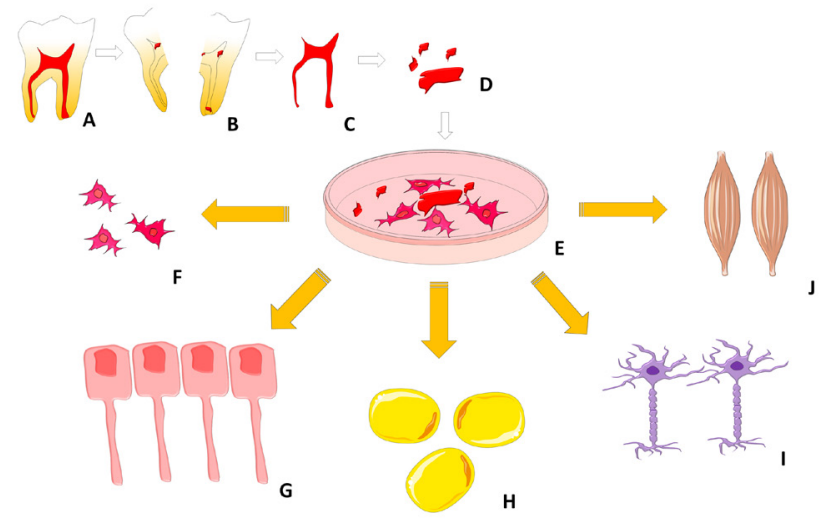

Figure 2. Schematic representation of stem cell isolation from pulp tissue by explant technique.

Note: A: extracted third molar; B: section of the tooth; C: removal of pulp tissue; D: pulp sectioned into small pieces; E: mesenchymal stem cells migrating from the pulp tissue cultured by the explant technique; $F$ : capacity for self-renewal of stem cells; G: odontoblastic cells; H: adipose cells; I: neural cells; J: muscle cells.

The stem cells present will migrate slowly from the tissue to the bottom of the dishes, thus establishing a primary culture $^{13}$. In order to extract only stem cells, it is necessary for culture media suitable for such cells to be used in both techniques. Although enzymatic digestion is a faster isolation method, studies have shown that the use of enzymes could be aggressive towards these cells. However, both techniques are considered adequate for obtaining stem cells ${ }^{13}$. Once an adequate amount of cells has been obtained, they can be used in SC-BT or safely frozen either in liquid nitrogen for up to 2 years or in a freezer at $-80^{\circ} \mathrm{C}$ for up to one year ${ }^{4}$.

\section{Bioactive molecules}

Growth factors are proteins with the ability to bind to specific sites of the cell membrane triggering intracellular reactions, signaling and modulating the behavior of these cells ${ }^{1}$. They can, for example, stimulate cell differentiation or deposition of dentin tissue ${ }^{12}$. Such molecules are present in various amounts in the tissues of the human body. In addition to being imprisoned in the dentin, they are present in venous blood mainly in platelet concentrates such as platelet-rich plasma (PRP) and platelet-rich fibrin (PRF) ${ }^{15}$. Several biomolecules are important for dentistry, among them the vascular endothelial growth factor (VEGF), family of TGF- $\beta$ and BMP are the most commonly reported in the literature, having a key role in the events of angiogenesis, dentin-pulp complex repair and bone repair ${ }^{12}$.

VEGF is the factor that regulates the pathophysiology of angiogenesis by inducing proliferation and differentiation of endothelial cells. Furthermore, its use in scaffolds may increase blood vessel anastomosis in addition to microvessel density, thereby providing proper nutrition for the establishment of the cell/scaffold assembly ${ }^{16}$. Mullane et al. ${ }^{17}$ tested different concentrations of VEGF and fibroblast growth factor-2 (FGF-2) and observed in vivo that, after fourteen days, the treatment with $50 \mathrm{ng} / \mathrm{mL}$ of VEGF was superior to the other groups and to the groups not treated with growth factors. This method increased the formation of anastomoses and blood vessel lumen in scaffolds surrounded by dental tissue of third molars implanted in the dorsum of mice.

Recent clinical trials have investigated the human application of recombinant human plateletderived growth factor BB (rhPDGF-BB) ${ }^{18-19}$ and BMP-20 in bone regeneration. Biopsies taken from the bone tissue removed during implant placement demonstrated that the bone regenerated with these growth factors had a larger number of blood vessels with a greater quantity of bone deposited. Other studies have presented the possibility of fully regenerating the complex structure of the periodontal ligament with these molecules. Control regions, without biomolecules, did not present periodontal regeneration, demonstrating the efficiency of these therapies based 
on growth factors ${ }^{21}$. Moreover, the literature presents just one case of the application of growth factors in root canal revascularization ${ }^{22}$. Fifteen months of follow-up demonstrated continuing root development and clinical success with the use of rhPDGF-BB in revascularization therapies ${ }^{22}$.

\section{Scaffolds in regenerative therapies}

Scaffolds are structures that provide a threedimensional substrate for cell adhesion and proliferation, analogous to the extracellular matrix ${ }^{1}$. They must provide an environment that possesses physico-chemical properties specific to each tissue, in order to favor cell growth and differentiation ${ }^{2}$. The main classification is based on its origin, which may be natural or synthetic.

Synthetic scaffolds, for the most part, are monomers that polymerize in long chains, thereby providing the scaffold's architecture 6 . These polymers must fundamentally enter the metabolic pathway of the cells and be degraded for their substitution by extracellular matrix to take place ${ }^{1,6}$. The most frequently used polymers in the construction of these scaffolds are poly-lactic acid (PLLA), poly-lactic-co-glycolic acid (PLGA) and hydrogels ${ }^{1,23-24}$. In addition to these polymers, ceramic scaffolds containing hydroxyapatite are also used ${ }^{5}$. Among the natural polymers, fibrin and collagen scaffolds are often employed and enjoy the advantages of having excellent cell compatibility since cells recognize these structures through their surface receptors ${ }^{7,25}$.

The spacing between the pores formed and the scaffold stiffness and topography will be important in determining the type of tissue formed ${ }^{26}$. Any change in this microenvironment is capable of altering cellular behavior. In addition, they have chemical receptors in their membranes and a range of tactile receptors capable of identifying minimal changes ${ }^{25}$. Thus reproducing a scaffold with all the desirable properties becomes an arduous task.

Gonçalves et al. ${ }^{16}$ used the tooth slice/scaffold (TS/S) model to evaluate the angiogenesis provided by VEGF in pulp-like tissues. TS/S is an in vivo model where horizontal sections in the region of the cement/enamel junction are performed, so the tissue that is present is removed. The presence of the surrounding dentin is one of the key points of the model, since its prior conditioning with ethylenediaminetetraacetic acid (EDTA) releases the growth factors trapped in this tissue ${ }^{26}$. In addition, the tooth slice obtained is filled by PLLA scaffolds and these are seeded with stem cells. The TS/S assembly is thus implanted on the dorsum of immunosuppressed mice, where it is possible to evaluate the interaction of the TS/S with the cells of the animal organism ${ }^{16}$.

\section{Blood plasmatic concentrations in regenerative therapies}

The use of blood plasmatic concentrates (PRP, PRF) has been extensively studied in the biomedical field for use as natural scaffolds in regenerative medicine ${ }^{7}$. These concentrates present, in addition to several interleukins, high concentrations of growth factors (TGF- $\beta$, VEGF, epithelial growth factor-EGF and insulin-like growth factor I), making them scaffolds that are naturally loaded with bioactive molecules ${ }^{15}$. The cost of these materials is lower than synthetic materials, which makes these therapies increasingly attractive, since the PRP does not interfere with the homeostatic balance, repairing the periodontal tissue ${ }^{7}$. In addition, complications such as those occurring with the use of non-biodegradable membranes for the treatment of root recessions, are rarely observed ${ }^{7}$. One disadvantage reported with the application of PRP is the use of animal reagents such as bovine thrombin, used as a coagulant in some processing techniques, which could cause coagulopathies ${ }^{15}$.

PRF, on the other hand, does not require reagents to obtain $\mathrm{it}^{15}$. It has emerged as a second generation of platelet concentrates and can generally be obtained by centrifugation of venous blood (Figure 3). In this way, fractionation processes are eliminated and exogenous reagents are not required. In addition, no immunological reactions are observed and the release of growth factors by PRF seems to be more appropriate than PRP, all of which supports the increasing application of this technique ${ }^{7}$. The peak release of TGF- $\beta$ in PRF occurs around the $14^{\text {th }}$ day when it is maintained for long periods, whereas in PRP the release occurs on the first day and more quickly ${ }^{27}$.

The clinical use of these concentrates has been increasingly applied in dentistry, obtaining promising results $^{15}$. Root coatings, regeneration of intraosseous periodontal defects, guided bone regeneration, adjuvants in osseointegration of implants and root canal revascularization are some of the techniques that already use this biological mode of treatment.

\section{Therapies for regeneration of periodontal tissue}

The main objective of periodontal regenerative therapy is the restructuring of the original architecture and function of the periodontal complex, involving the formation of new cementum at the root of the tooth, as 
well as the new periodontal insertion between the newly formed bone and cementum ${ }^{28-29}$. This therapy, therefore, uses specific techniques aimed at restoring tooth support segments that have been lost as a result of periodontitis or gingival trauma ${ }^{30}$.

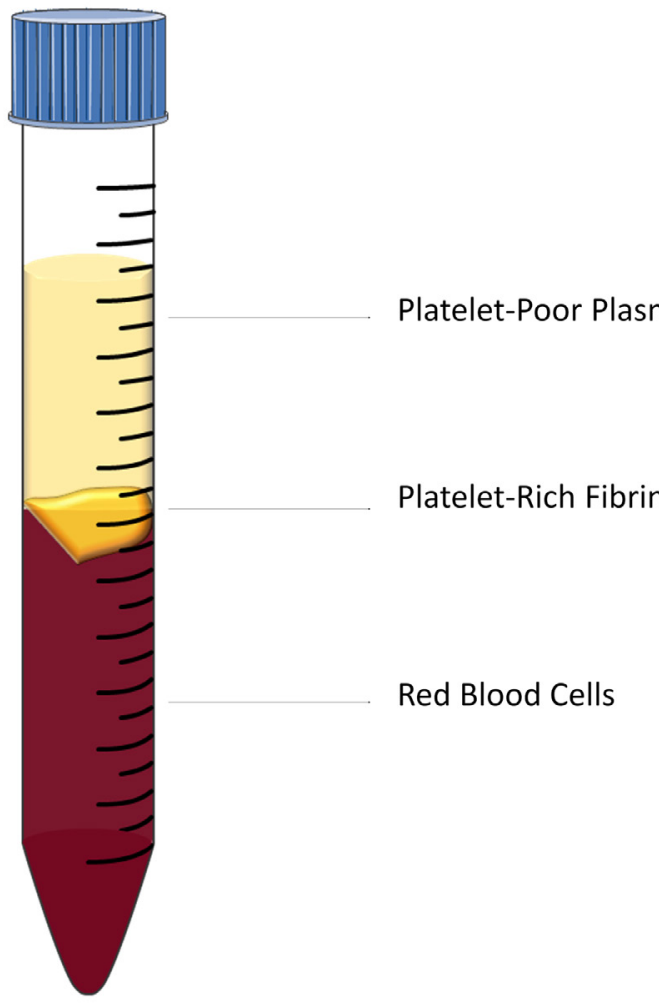

Figure 3. Result of obtaining PRF by centrifugation technique.

The literature has presented several in vitro and in vivo studies reporting a variety of approaches for this type of regenerative technique ${ }^{31-32}$. Duan et al. ${ }^{32}$, investigated the ability of induced pluripotent stem cells (iPSC) and enamel matrix derivatives (EMD) to repair periodontal defects in mice. In this study, periodontal regeneration through iPSC and the consequent formation of alveolar bone, cementum and periodontal ligament were observed. In addition, other in vivo studies using iPSC have decreased experimental periodontitis, inhibiting alveolar bone resorption. Thus, these methods may represent alternatives for periodontal treatment and regeneration ${ }^{33}$.

Although many of the studies conducted are in vitro and performed on animal models, some clinical trials have been conducted. Sharma and Pradeep ${ }^{9}$ conducted a randomized clinical trial of 35 patients in which they evaluated the efficacy of autologous PRF in the treatment of intraosseous defects in patients with chronic periodontitis. After nine months of follow-up, the group of patients who underwent surgical treatment with the addition of PRF showed better clinical and radiographic results when compared to the technique without PRF. In addition, Pradeep et al. ${ }^{34}$ conducted another randomized clinical trial comparing the treatment of regenerated bone defects with PRP and PRF. Although no statistical difference was found between PRP and PRF, they were statistically superior to the control group that did not use such blood concentrates ${ }^{34}$. In addition, the use of PRF $+1 \%$ of Metformin (a secondgeneration biguanide with osteoblastic activity and collagen formation) increased bone repair when compared to PRF and to conventional techniques ${ }^{35}$.

\section{Therapies for the regeneration of bone tissue}

Regeneration of bone tissue may be an interesting strategy in cases of maxillary corrections after trauma, implant-supported rehabilitation, in regions with atrophic bone tissue, and in the filling of bone defects or in intraosseous pathologies ${ }^{36-38}$. Although the incorporation of active compounds into titanium surfaces, for example, may increase biological tissue activity ${ }^{39}$, the direct application of stem cells, mainly from adipose tissue and bone marrow, has produced excellent results ${ }^{36-37}$. Most of the studies seeking bone regeneration in the maxillomandibular region have used BMSC from the iliac crest ${ }^{36}$. Kaigler et al..$^{36}$ undertook a randomized clinical trial with thirty patients who underwent surgery for maxillary sinus augmentation. Scaffolds of $\beta$-tricalcium phosphate seeded with autologous BMSC were used in sinus elevation. Four months after implantation, radiographic analysis did not show any difference in terms of bone gain, but a higher bone density was evidenced in patients who underwent cellular therapies with BMSC. After one year, implant placement surgeries were performed and the bone tissue removed during surgery was analyzed, demonstrating higher bone quality in patients who used BMSC $^{36}$. Another similar study using BMSC, now combined with injectable PRP as a scaffold, also observed favorable results. Even after six years of follow-up no adverse effects were observed, demonstrating safety in the use of cellular therapies ${ }^{37}$. Similar results have been observed with the use of ASC even with the reconstruction of large mandibular defects $^{40}$. Moreover, the use of stem cells from the dental pulp in synthetic scaffolds also obtained a positive result in 
the regeneration of bone defects in mice, when compared to the groups without stem cells ${ }^{41}$. Acar et al..$^{42}$ performed computerized microtomography and histomorphometric analysis on bone defects produced in mice calvaria, repaired with PRF and Straumann ${ }^{\circledR}$ Bone Ceramic (SBC). It was found that both exhibited better bone regeneration than the control group. In addition, a synergistic effect was observed when the PRF was used with the SBC, further enhancing bone repair.

A recent study evaluated radiographically the impact of the increase of PRP in the vicinity of oral implants of 30 different patients. The results showed that the addition of PRP may be beneficial since a significant positive effect occurred ${ }^{43}$. D'Aquino et al. ${ }^{44}$ performed autologous DPSC grafts in 7 patients (followed up for 1 year) who presented bone resorption in the second molar distal due to impacted inferior third molars. These defects had no walls and were at least 1.5 centimeters high. In this way, the upper third molars were first extracted to obtain and expand the DPSC. After 3 months, the third molars that had caused the bone defects were extracted. Then the DPSC were seeded in a collagen scaffold and grafted at the sites of the bone defects. This study demonstrated that the autologous application of stem cells can be used with low risk to humans, being a therapeutic strategy for the regeneration of bone tissue ${ }^{44}$. In 2013, the follow-up of these cases was republished ${ }^{8}$. Three years after carrying out the grafts, a mini-invasive surgery was performed at the site of the grafts in order to observe the tissue formed. Several analyses showed that the regenerated tissue was in excellent condition and no tissue alteration was found. In addition, the regenerated bone presented vascularization and a compact rather than spongy bone, contrary to what was expected for the region. This may be because DPSCs do not follow the local signals of the surrounding spongy bone $^{8}$. In any case, these studies demonstrate that the clinical transition of SC-BT is taking place.

\section{Root canal revascularization}

Root canal revascularization (maturogenesis) is a recent technique that aims to reestablish a tissue similar to pulp in the root canal of necrotic teeth with incomplete apex ${ }^{45}$. It is based on the stem cells of the apical papilla present at the apex of the dental elements undergoing root development. Thus, decontamination of the root canal is performed with a tri-antibiotic paste (usually composed of Metronidazole, Ciprofloxacin and (efaclor), which remains in the root canal until all the clinical signs of infection have receded ${ }^{45}$. The apical periodontium is then stimulated with an endodontic file until bleeding occurs at the apex of the tooth, which in turn will fill the space of the root canal. This blood is coagulated after a few minutes, forming a natural scaffold. After blood clotting, an MTA plug is deposited on the blood clot and the tooth is restored ${ }^{45}$. This procedure provides for the continuation of the development of the apical portion of the tooth root and the filling of the canal with a regenerated/repaired tissue (Figure 4).

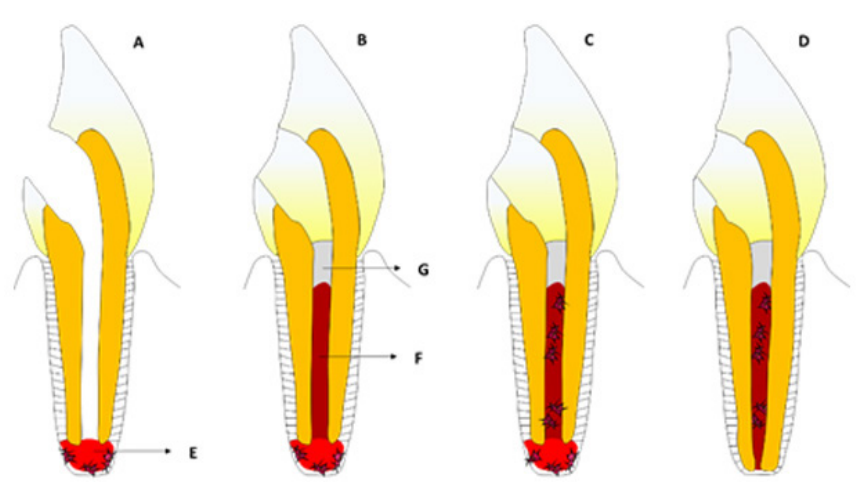

Figure 4. Schematic drawing of the root canal revascularization principle. A) Necrotic permanent tooth with incomplete apex B) Blood clot formation and MTA plug application; C) Migration of apical papilla stem cells; D) Continuation of root development; E) Apical papilla with presence of stem cells; F) Blood clot; G) MTA Plug

Successes in clinical cases have been reported in the literature. Kottoor \& Velmurugan ${ }^{46}$ monitored a successful clinical case for 60 months, while McTigue et al. ${ }^{47}$ obtained success in 32 teeth with an average of 51 months of followup. These results seem to indicate that the technique appears to be effective. A recent scoping review that examined 75 revascularization studies noted that the more recent studies have applied PRP or PRF as natural scaffolds in the root canal ${ }^{45}$. Such studies have shown excellent results with continuing development of the tooth root and deposition of mineralized tissue on the walls of the canals, observed radiographically.

\section{DISCUSSION}

The maintenance and reestablishment of biological structures are the main objectives of SC-BT2. These therapies, although recent, have been extensively studied over the last two decades. Several in vivo study models have been developed and conducted using many cell lines ${ }^{1,2,36,38,40}$. Synthetic and natural scaffolds have been 
developed and applied successfully ${ }^{16,24,26}$. Moreover, several techniques used in modern clinical dentistry emerged from the application of tissue engineering principles.

The use of growth factors and platelet concentrates are an example of how such approaches are present and growing in dentistry ${ }^{15,21-22}$. The use of PRP was the first generation of blood concentrates to be used with the aim of improving bone repair in surgeries ${ }^{7}$. The use of PRF appeared soon afterwards, in the second generation, and seems to have advantages over the use of PRP. In addition, to not requiring the use of xenogeneic compounds for their preparation, the PRF can be obtained through a single centrifugation step. Another advantage is the release of bioactive molecules, which seems to be more efficient in fibrin concentrates. Platelet compounds have several bioactive molecules capable of stimulating cell migration, differentiation and proliferation ${ }^{48}$. In this way, blood plasma concentrates, in addition to acting as excellent scaffolds for cell adhesion, are naturally loaded with growth factors, which does not occur with synthetic scaffolds, which need to be loaded individually ${ }^{15}$.

In order to facilitate the release of growth factors, gene therapy is a new technique that can be employed for this purpose. The manipulation of stem cell genetic material can be performed to encode specific protein sequences. Thus, genes encoding growth factors can be inserted into these cells, which would then produce these proteins when they are active at the implant site. Therefore, small doses of these factors could be released continuously by stimulating the regeneration of the tissue in question ${ }^{10}$.

Although promising, gene therapies are in the early stages of research and their use in humans has not yet been realized. However, recent studies using autologous DPSC, ASC and BMSC have been implemented for the repair of bone tissue in humans, producing encouraging results $8,36,38,40,44$. Follow-up periods of 3 and 6 years demonstrate that this technique can be considered safe for use in humans $s^{8,37}$. The use of stem cells of autologous origin is considered a facilitating factor in the use of SC-BT, since they can be obtained from several sites in the patient's oral cavity and do not trigger immune response ${ }^{44}$. Thus, the development of human tooth banks for cryopreservation is fundamental for the clinical translation of SC-BT4. Exfoliated deciduous teeth are often discarded despite being multipotent stem cells. Extracted third molars present stem cells in the periodontal pulp tissue and the apical papilla (in the root development stage) that can be used in future regenerative therapies ${ }^{1,3}$.

The presence of stem cells in the apical papilla of teeth with incomplete rhizogenesis is the principle used in recent root canal revascularization techniques ${ }^{45}$. The blood clot formed acts as a scaffold where the adhesion of the stem cells migrating to that region occurs. The use of blood concentrates may contribute to the recruitment of these cells, since PRP and PRF are naturally loaded with growth factors ${ }^{45}$. Despite this, few studies have evaluated histologically the tissues formed inside the root canal. The presence of odontoblast cells or pulp-like tissue was not observed, however, a mineralized tissue similar to cementum and bone tissue was evidenced ${ }^{49-50}$. There has been speculation that the intensity of the previous necrosis could be a determining factor in the viability of the remaining stem cells. Very severe necrosis could make these cells unviable ${ }^{49-50}$. Perhaps in these cases it is important to use stem cells from other regions to ensure the regeneration of pulp tissue.

The observation of continuing development of the root of the dental element in several clinical cases of revascularization seems to favor the prognosis of immature teeth, since these techniques reestablish the vitality of the dental element that was previously necrosed. Thus, elements submitted to revascularization tend to respond positively to thermal and electrical sensitivity tests, similar to healthy teeth ${ }^{45}$.

\section{FINAL CONSIDERATIONS}

The use of regenerative therapies in dental practice is a reality. Despite being in the early stages, such approaches are growing. Grafts containing autologous growth factors and stem cells have already been implanted in humans, obtaining clinical success in bone and periodontal regeneration. In addition, tissue engineering principles are applied in root canal revascularization techniques as well as in several regenerative procedures (bone, periodontal and pulp) using PRP and PRF, demonstrating a paradigm shift in dentistry.

\section{Collaborators}

LA CHISINI contributed to conception, research, literature review, interpretation, article writing and critically revised the manuscript. GT DEMARCO, LB KIRSCHNICK and LB WATSON contributed to literature review and paper writing. FF DEMARCO and MCM CONDE drafted and critically revised the manuscript. All authors gave their final approval and agreed to be accountable for all aspects of 
research.

\section{REFERENCES}

1. Demarco FF, Conde MC, Cavalcanti BN, Casagrande L, Sakai VT, Nor JE. Dental pulp tissue engineering. Braz Dent J. 2011;22(1):313. doi: 10.1590/S0103-64402011000100001

2. Conde MC, Chisini LA, Demarco FF, Nor JE, Casagrande L, Tarquinio SB. Stem cell-based pulp tissue engineering: variables enrolled in translation from the bench to the bedside, a systematic review of literature. Int Endod J. 2016 Jun;49(6):543-50. doi: 10.1111/iej.12489

3. Gronthos S, Mankani M, Brahim J, Robey PG, Shi S. Postnatal human dental pulp stem cells (DPSCs) in vitro and in vivo. Proc Natl Acad Sci U S A. 2000 Dec 5;97(25):13625-30. doi: 10.1073/ pnas.240309797

4. Conde M, Chisini L, Grazioli G, Francia A, de Carvalho R, Alcázar $J$, et al. Does cryopreservation affect the biological properties of stem cells from dental tissues? A systematic review. Braz Dent J. 2016;27(6):633-40. doi: 10.1590/0103-6440201600980

5. Zhang W, Walboomers XF, van Osch GJ, van den Dolder J, Jansen JA. Hard tissue formation in a porous HATTCP ceramic scaffold loaded with stromal cells derived from dental pulp and bone marrow. Tissue Eng Part A. 2008 Feb;14(2):285-94. doi: 10.1089/ tea.2007.0146.

6. Young CS, Terada S, Vacanti JP, Honda M, Bartlett JD, Yelick PC Tissue engineering of complex tooth structures on biodegradable polymer scaffolds. J Dent Res. 2002 Oct;81(10):695-700. doi: org ez238. periodicos.capes.gov.br/10.1177/154405910208101008

7. Kawase T. Platelet-rich plasma and its derivatives as promising bioactive materials for regenerative medicine: basic principles and concepts underlying recent advances. Odontology. 2015 May;103(2):126-35. doi: 10.1007/s10266-015-0209-2

8. Giuliani A, Manescu A, Langer M, Rustichelli F, Desiderio V, Paino F, et al. Three years after transplants in human mandibles, histological and in-line holotomography revealed that stem cells regenerated a compact rather than a spongy bone: biological and clinical implications. Stem Cells Transl Med. 2013 Apr;2(4):316-24. doi: $10.5966 / \mathrm{sctm} .2012-0136$

9. Sharma A, Pradeep AR. Treatment of 3-wall intrabony defects in patients with chronic periodontitis with autologous platelet-rich fibrin: a randomized controlled clinical trial. J Periodontol. 2011 Dec;82(12):1705-12. doi: 10.1902/jop.2011.110075

10. Jabbarzadeh E, Starnes T, Khan YM, Jiang T, Wirtel AJ, Deng M, et al. Induction of angiogenesis in tissue-engineered scaffolds designed for bone repair: a combined gene therapy-cell transplantation approach. Proc Natl Acad Sci U S A. 2008 12;105(32):11099-104. doi: 10.1073/pnas.0800069105

11. Chisini LA, Conde MC, Correa MB, Dantas RV, Silva AF, Pappen FG, et al. Vital pulp therapies in clinical practice: findings from a survey with dentist in Southern Brazil. Braz Dent J. 2015 ;26(6):566-71. doi: 10.1590/0103-6440201300409

12. Goldberg M, Six N, Decup F, Buch D, Soheili Majd E, Lasfargues JJ, et al. Application of bioactive molecules in pulp-capping situations. Adv Dent Res. 2001;15:91-5. doi: 10.1177/08959374010150012401
13. Hilkens P, Gervois P, Fanton Y, Vanormelingen J, Martens W, Struys $T$, et al. Effect of isolation methodology on stem cell properties and multilineage differentiation potential of human dental pulp stem cells. Cell Tissue Res. 2013;353(1):65-78. doi: 10.1007/s00441013-1630-x

14. Huang GT, Sonoyama W, Chen J, Park SH. In vitro characterization of human dental pulp cells: various isolation methods and culturing environments. Cell Tissue Res. 2006;324(2):225-36. doi: 10.1007/s00441-005-0117-9

15. Borie E, Olivi DG, Orsi IA, Garlet K, Weber B, Beltran $\mathrm{V}$, et al Platelet-rich fibrin application in dentistry: a literature review. Int J Clin Exp Med. 2015;8(5):7922-9.

16. Goncalves SB, Dong Z, Bramante CM, Holland GR, Smith AJ Nor JE. Tooth slice-based models for the study of human denta pulp angiogenesis. J Endod. 2007;33(7):811-4. doi: 10.1016/j. joen.2007.03.012

17. Mullane EM, Dong Z, Sedgley CM, Hu JC, Botero TM, Holland GR, et al. Effects of VEGF and FGF2 on the revascularization of severed human dental pulps. J Dent Res. 2008;87(12):1144-8. doi: $10.1177 / 154405910808701204$

18. Nevins ML, Camelo M, Schupbach $P$, Nevins M, Kim SW, Kim DM. Human buccal plate extraction socket regeneration with recombinant human platelet-derived growth factor BB or enamel matrix derivative. Int J Periodontics Restorative Dent. 2011;31(5):481-92.

19. Nevins M, Giannobile WV, McGuire MK, Kao RT, Mellonig JT, Hinrichs JE, et al. Platelet-derived growth factor stimulates bone fill and rate of attachment level gain: results of a large multicenter randomized controlled trial. J Periodontol. 2005 Dec;76(12):220515. doi: 10.1902/jop.2005.76.12.2205

20. Schuckert KH, Jopp S, Osadnik M. Modern bone regeneration instead of bone transplantation: a combination of recombinant human bone morphogenetic protein- 2 and platelet-rich plasma for the vertical augmentation of the maxillary bone-a single case report. Tissue Eng Part C Methods. 2010;16(6):1335-46. doi: 10.1089/ten.TEC.2010.0020

21. Nevins M, Camelo M, Nevins ML, Schenk RK, Lynch SE. Periodontal regeneration in humans using recombinant human platelet-derived growth factor-BB (rhPDGF-BB) and allogenic bone. J Periodontol. 2003;74(9):1282-92. doi: 10.1902/jop.2003.74.9.1282

22. Zhujiang A, Kim SG. Regenerative endodontic treatment of an immature necrotic molar with arrested root development by using recombinant human platelet-derived growth factor: a case report. J Endod. 2016 ;42(1):72-5. doi: 10.1016/j.joen.2015.08.026.

23. Cavalcanti BN, Zeitlin BD, Nor JE. A hydrogel scaffold that maintains viability and supports differentiation of dental pulp stem cells. Dent Mater. 2013;29(1):97-102. doi: 10.1016/j.dental.2012.08.002

24. Chisini LA, Conde MC, Alcazar JC, Silva AF, Nor JE, Tarquinio $\mathrm{SB}$, et al. Immunohistochemical Expression of TGF-beta1 and osteonectin in engineered and $\mathrm{Ca}(\mathrm{OH}) 2$-repaired human pulp tissues. Braz Oral Res. 2016;30(1):e93. doi: 10.1590/18073107BOR-2016.vol30.0093

25. Gattazzo F, Urciuolo A, Bonaldo P. Extracellular matrix: a dynamic microenvironment for stem cell niche. Biochim Biophys Acta. 2014;1840(8):2506-19. doi: 10.1016/j.bbagen.2014.01.010 
26. Demarco FF, Casagrande L, Zhang Z, Dong Z, Tarquinio SB, Zeitlin $B D$, et al. Effects of morphogen and scaffold porogen on the differentiation of dental pulp stem cells. J Endod. 2010;36(11):1805-11. doi: 10.1016/j.joen.2010.08.031

27. He L, Lin $Y, H u X$, Zhang $Y$, Wu H. A comparative study of plateletrich fibrin (PRF) and platelet-rich plasma (PRP) on the effect of proliferation and differentiation of rat osteoblasts in vitro. Oral Surg Oral Med Oral Pathol Oral Radiol Endod. 2009;108(5):70713. doi: 10.1016/j.tripleo.2009.06.044

28. Ivanovski S. Periodontal regeneration. Aust Dent J. 2009;54(Suppl 1):S118-28. doi: 10.1111/j.1834-7819.2009.01150.x

29. Ivanovski S, Vaquette C, Gronthos S, Hutmacher DW, Bartold PM. Multiphasic scaffolds for periodontal tissue engineering. J Dent Res. 2014;93(12):1212-21. doi: 10.1177/0022034514544301

30. Ramseier CA, Rasperini G, Batia S, Giannobile WV. Advanced reconstructive technologies for periodontal tissue repair. Periodontol 2000. 2012;59(1):185-202. doi: 10.1111/j.16000757.2011.00432.x

31. Hynes K, Menicanin D, Han J, Marino V, Mrozik K, Gronthos $S$, et al. Mesenchymal stem cells from iPS cells facilitate periodontal regeneration. J Dent Res. 2013;92(9):833-9. doi: $10.1177 / 0022034513498258$

32. Duan X, Tu Q, Zhang J, Ye J, Sommer C, Mostoslavsky G, et al. Application of induced pluripotent stem (iPS) cells in periodontal tissue regeneration. J Cell Physiol. 2011;226(1):150-7. doi: 10.1002/jcp.22316

33. Yang $H$, Aprecio RM, Zhou $X$, Wang $Q$, Zhang $W$, Ding $Y$, et al. Therapeutic effect of TSG-6 engineered iPSC-derived MSCS on experimental periodontitis in rats: a pilot study. PLoS One. 2014;9(6):e100285. doi: 10.1371/journal.pone.0100285

34. Pradeep AR, Rao NS, Agarwal E, Bajaj P, Kumari M, Naik SB Comparative evaluation of autologous platelet-rich fibrin and platelet-rich plasma in the treatment of 3-wall intrabony defects in chronic periodontitis: a randomized controlled clinical trial. J Periodontol. 2012;83(12):1499-507. doi: 10.1902/ jop.2012.110705

35. Pradeep AR, Nagpal K, Karvekar S, Patnaik K, Naik SB, Guruprasad CN. Platelet-rich fibrin with $1 \%$ metformin for the treatment of intrabony defects in chronic periodontitis: a randomized controlled clinical trial. J Periodontol. 2015;86(6):729-37. doi: 10.1902/jop.2015.140646

36. Kaigler D, Avila-Ortiz G, Travan S, Taut AD, Padial-Molina M, Rudek l, et al. Bone Engineering of maxillary sinus bone deficiencies using enriched cd90+ stem cell therapy: a randomized clinical trial. J Bone Miner Res. 2015;30(7):1206-16. doi: 10.1002/jbmr.2464

37. Yamada $Y$, Nakamura $S$, Ito $K$, Kohgo T, Hibi H, Nagasaka T, et al. Injectable tissue-engineered bone using autogenous bone marrow-derived stromal cells for maxillary sinus augmentation: clinical application report from a 2-6-year follow-up. Tissue Eng Part A. 2008;14(10):1699-707. doi: 10.1089/ten.tea.2007.0189

38. Rickert D, Vissink A, Slot WJ, Sauerbier S, Meijer HJ, Raghoebar GM. Maxillary sinus floor elevation surgery with BioOss $(R)$ mixed with a bone marrow concentrate or autogenous bone: test of principle on implant survival and clinical performance. Int J Oral Maxillofac Surg. 2014;43(2):243-7. doi: 10.1016/j.ijom.2013.09.006
39. Alcazar JC, Salas MM, Conde MC, Chisini LA, Demarco FF, Tarquinio SB, et al. Electrochemical cathodic polarization, a simplified method that can modified and increase the biological activity of titanium surfaces: a systematic review. PLoS One. 2016;11(7):e0155231. doi: 10.1371/journal.pone.0155231

40. Sandor GK, Tuovinen VJ, Wolff J, Patrikoski M, Jokinen J, Nieminen $\mathrm{E}$, et al. Adipose stem cell tissue-engineered construct used to treat large anterior mandibular defect: a case report and review of the clinical application of good manufacturing practice-level adipose stem cells for bone regeneration. J Oral Maxillofac Surg. 2013;71(5):938-50. doi: 10.1016/j.joms.2012.11.014

41. Asutay F, Polat S, Gul M, Subasi C, Kahraman SA, Karaoz E. The effects of dental pulp stem cells on bone regeneration in rat calvarial defect model: Micro-computed tomography and histomorphometric analysis. Arch Oral Biol. 2015;60(12):172935. doi: 10.1016/j.archoralbio.2015.09.002

42. Acar AH, Yolcu U, Gul M, Keles A, Erdem NF, Altundag Kahraman S. Micro-computed tomography and histomorphometric analysis of the effects of platelet-rich fibrin on bone regeneration in the rabbit calvarium. Arch Oral Biol. 2015;60(4):606-14. doi: 10.1016/j.archoralbio.2014.09.017

43. Georgakopoulos I, Tsantis S, Georgakopoulos P, Korfiatis $P_{t}$ Fanti $E$, Martelli $M$, et al. The impact of Platelet Rich Plasma (PRP) in osseointegration of oral implants in dental panoramic radiography: texture based evaluation. Clin Cases Miner Bone Metab. 2014;11(1):59-66.

44. D'Aquino R, De Rosa A, Lanza V, Tirino V, Laino L, Graziano A, et al. Human mandible bone defect repair by the grafting of dental pulp stem/progenitor cells and collagen sponge biocomplexes. Eur Cell Mater. 2009;18:75-83. doi: 10.22203/eCM

45. Conde MC, Chisini LA, Sarkis-Onofre R, Schuch HS, Nor JE, Demarco FF. A scoping review of root canal revascularization: relevant aspects for clinical success and tissue formation. Int Endod J. 2016;50(9):860-87. doi: 10.1111/iej.12711

46. Kottoor J, Velmurugan N. Revascularization for a necrotic immature permanent lateral incisor: a case report and literature review. Int $J$ Paediatr Dent. 2013:23(4):310-6. doi: 10.1111/ipd.12000

47. McTique DJ, Subramanian K, Kumar A. Case series: management of immature permanent teeth with pulpal necrosis: a case series. Pediatr Dent. 2013;35(1):55-60.

48. Huang FM, Yang SF, Zhao JH, Chang YC. Platelet-rich fibrin increases proliferation and differentiation of human dental pulp cells. J Endod. 2010;36(10):1628-32. doi: 10.1016/j.joen.2010.07.004

49. Martin G, Ricucci D, Gibbs JL, Lin LM. Histological findings of revascularized/revitalized immature permanent molar with apical periodontitis using platelet-rich plasma. J Endod. 2013;39(1):13844. doi: 10.1016/j.joen.2012.09.015

50. Becerra P, Ricucci D, Loghin S, Gibbs JL, Lin LM. Histologic study of a human immature permanent premolar with chronic apical abscess after revascularization/revitalization. J Endod. 2014;40(1):133-9. doi: 10.1016/j.joen.2013.07.017

Received on: 19/12/2016 Final version resubmitted on: 17/6/2017 Approved on: 19/10/2017 